\title{
Pengaruh Pupuk Hayati Evagrow Terhadap Pertumbuhan Dan Hasil Tanaman Seledri (Apium graveolens L.)
}

\author{
Nining Sri Sukasih \\ Fakultas Pertanian Universitas Kapuas Sintang \\ e-mail : niningskasih@g.mail.com
}

\begin{abstract}
Abstrak: Penelitiani ini bertujuan untuk mengetahui pengaruh pupuk hayati evagrow terhadap pertumbuhan dan hasil tanaman seledri dan untuk mendapatkan dosis pupuk hayati evagrow yang akan menghasilkan pertumbuhan dan hasil tanaman seledri tertinggi. Hasil penelitian diketahui bahwa pupuk hayati evagrow berpengaruh nyata terhadap pertumbuhan dan hasil tanaman seledri berdasarkan hasil pengamatan terhadap tinggi tanaman, jumlah daun, dan berat segar tanaman. Pemberian 10 gram pupuk hayati evagrow menghasilkan pertumbuhan dan hasil tertinggi tanaman seledri dalam penelitian ini. Tinggi tanaman rata-rata $36,00 \mathrm{~cm}$, jumlah daun rata-rata 42,80 daun, dan rata-rata berat segar 66,00 gram per tanaman.
\end{abstract}

Kata kunci: pupuk hayati evagrow, seledri, pertumbuhan, hasil.

\section{PENDAHULUAN}

Seledri (Apium graveolens L.) adalah jenis sayuran yang sangat popular saat ini terutama untuk kebutuhan seharihari, hal ini akan terus bertambah sejalan dengan bertambahnya jumlah penduduk serta kesadaran masyarakat akan pentingnya kebutuhan gizi seimbang.

Peningkatan produksi pertanian tidak terlepas dari peranan pupuk sebagai bahan penyubur. Kebutuhan akan bahan organik terus meningkat sejalan dengan semakin menurunnya kesuburan tanah, rusaknya sifat fisik dan kimia tanah, rendahnya daya ikat terhadap air hujan dan menurunnya persediaan bahan organik dalam tanah. Salah satu pupuk hayati yang dapat diberikan lewat tanah serta dapat memperbaiki sifat fisik dan kimia, serta biologi tanah adalah pupuk hayati evagrow.

\section{METODOLOGI PENELITIAN}

\section{Metote Penelitian}

Rancangan yang digunakan dalam penelitian ini adalah pola Rancangan Acak Kelompok (RAK) satu faktorial dengan Enam kali ulangan. Faktor Perlakuan pupuk hayati evagrow terdiri dari 6 level perlakuan yaitu: $\mathrm{E}_{0}=$ tidak diberi evagrow, $\mathrm{E}_{1}=2,5 \mathrm{~g}$ evagrow per liter air, $\mathrm{E}_{2}=5 \mathrm{~g}$ evagrow per liter air, $E_{3}=7,5 \mathrm{~g}$ evagrow per liter air, $\mathrm{E}_{4}=10$

$\mathrm{g}$ evagrow per liter air, $\mathrm{E}_{5}=12,5 \mathrm{~g}$ evagrow per liter air. 


\section{Bahan dan Alat Penelitian}

Bahan yang digunakan dalam penelitian ini adalah benih seledri, pupuk hayati evagrow, pupuk kandang kotoran ayam, pestisida decis dan dithane-M45, furadan $3 \mathrm{G}$, daun kelapa sawit. Alat yang digunakan dalam penelitian ini adalah cangkul , meteran, sprayer, kamera, alat tulis.

\section{Waktu dan Tempat Penelitian}

Penelitian ini mulai dilaksanakan pada bulan Juli sampai dengan September 2017 di Kecamatan Sintang Kabupaten Sintang.

\section{HASIL DAN PEMBAHASAN}

\section{Hasil Penelitian}

1. Tinggi Tanaman

Hasil analisis ragam pengaruh perlakuan pupuk hayati evagrow terhadap tinggi tanaman ditampilkan dalam Tabel 1 dan 2.

Tabel 1. Analisis ragam pengaruh pupuk hayati evagrow terhadap tinggi tanaman $(\mathrm{cm})$

\begin{tabular}{|c|c|c|c|c|c|c|}
\hline \multirow{2}{*}{ SK } & \multirow{2}{*}{ DB } & \multirow{2}{*}{ JK } & \multirow{2}{*}{ KT } & \multirow{2}{*}{ F-hitung } & \multicolumn{2}{|c|}{ F-tabel } \\
\hline & & & & & 0,05 & 0,01 \\
\hline Ulangan & 4 & 27,20 & 6,80 & $0,60^{\mathrm{tn}}$ & 2,87 & 4,43 \\
\hline Perlakuan & 5 & 410,67 & 82,13 & $7,28^{* *}$ & 2,71 & 4,10 \\
\hline Galat & 20 & 225,70 & 11,29 & & & \\
\hline Total & 29 & 663,58 & & $\mathrm{kk}=$ & $11,07 \%$ & \\
\hline Sumber & \multicolumn{6}{|c|}{ : Data pengamatan, 2017} \\
\hline Keterangan & $:$ tn & \multicolumn{5}{|c|}{$\begin{array}{l}=\text { pengaruh tidak nyata pada taraf } 95 \% \\
=\text { pengaruh nyata pada taraf } 99 \%\end{array}$} \\
\hline
\end{tabular}

Tabel 2. Uji BNJ pemberian pupuk hayati evagrow terhadap tinggi tanaman (cm)

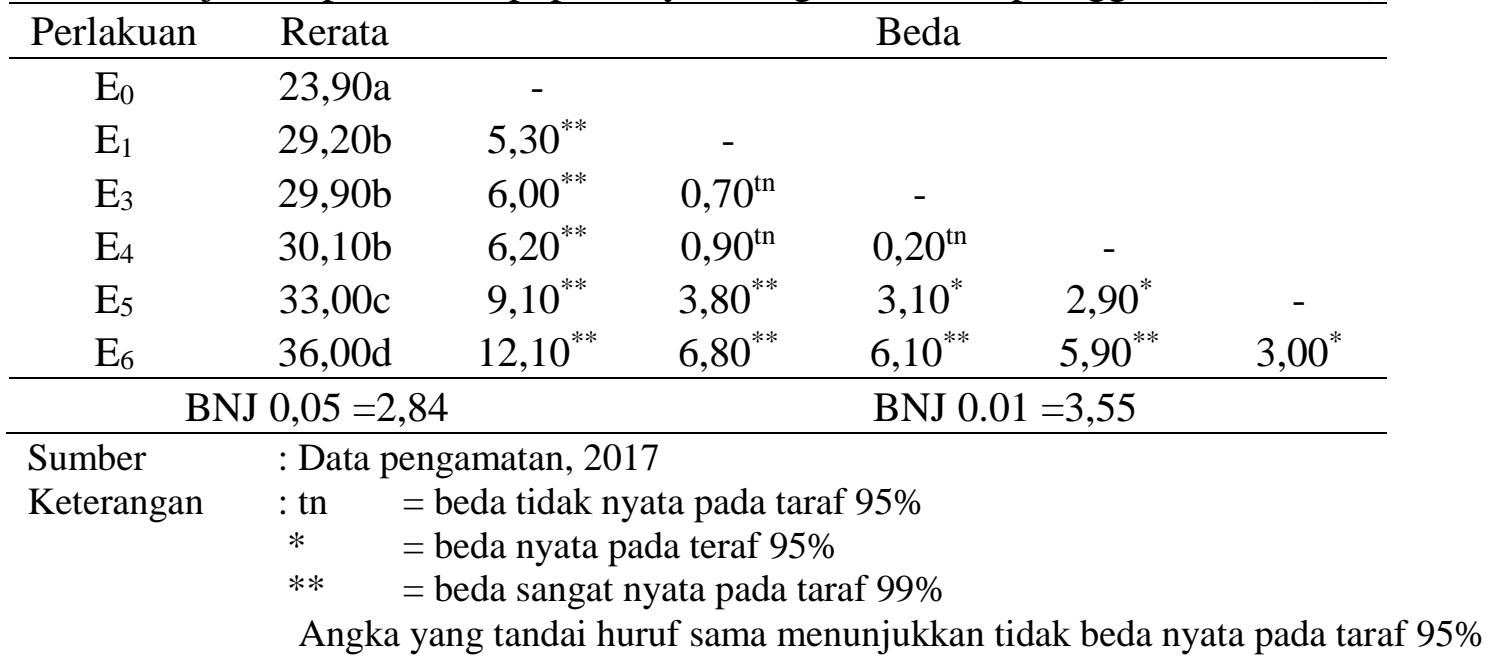


Uji BNJ pada Tabel 2 memperlihatkan bahwa pemberian 10 gram evagrow menghasilkan tanaman tertinggi dengan rata-rata $36,00 \mathrm{~cm}$ per tanaman. Pada pemberian 5 gram tinggi tanaman yang dihasilkan tidak lebih baik dari tanaman yang diberi 2,5 dan 12,5 gram, tetapi lebih tinggi dari tanaman yang tidak diberi evagrow.

\section{Jumlah Daun}

Data rerata hasil pengamatan per tanaman ditampilkan dalam Tabel 3.

Tabel 3. Data rerata pengataman jumlah daun (helai)

\begin{tabular}{cccccccc}
\hline \multirow{2}{*}{ Perlakuan } & \multicolumn{7}{c}{ Ulangan } \\
\cline { 2 - 6 } & I & II & III & IV & V & \multirow{2}{*}{ Jumlah } & Rerata \\
\hline $\mathrm{E}_{0}$ & 9,50 & 14,00 & 23,50 & 20,00 & 14,00 & 81,00 & 16,20 \\
$\mathrm{E}_{1}$ & 27,50 & 30,50 & 37,00 & 21,00 & 24,50 & 40,50 & 28,10 \\
$\mathrm{E}_{3}$ & 21,50 & 36,50 & 38,00 & 25,00 & 27,50 & 48,50 & 29,70 \\
$\mathrm{E}_{4}$ & 22,50 & 57,00 & 49,00 & 26,50 & 23,00 & 78,00 & 35,60 \\
$\mathrm{E}_{5}$ & 38,00 & 51,00 & 43,00 & 36,00 & 46,00 & 214,00 & 42,80 \\
$\mathrm{E}_{6}$ & 13,00 & 18,50 & 24,00 & 23,00 & 17,00 & 95,50 & 19,10 \\
\hline Total & 132,00 & 207,50 & 214,50 & 151,50 & 152,00 & 857,50 & 28,58 \\
\hline
\end{tabular}

Sumber: Data pengamatan, 2017

Tabel 4. Analisis ragampengaruh pupuk hayati evagrow terhadap jumlah daun (helai)

\begin{tabular}{ccccccc}
\multirow{2}{*}{ SK } & \multirow{2}{*}{ DB } & \multirow{2}{*}{ JK } & KT & F-hitung & \multicolumn{2}{c}{ F-tabel } \\
\cline { 6 - 7 } & & & & & 0,05 & 0,01 \\
\hline Ulangan & 4 & 914,25 & 228,56 & $5,41^{* *}$ & 2,87 & 4,43 \\
Perlakuan & 5 & 2480,54 & 496,11 & $11,75^{* *}$ & 2,71 & 4,10 \\
Galat & 20 & 844,75 & 42,24 & & & \\
\hline Total & 29 & 4239,54 & & $\mathrm{kk}=$ & $22,74 \%$ \\
\hline Sumber & $:$ Data pengamatan, 2017 & & & \\
Keterangan & $: * * \quad=$ pengaruh nyata pada taraf $99 \%$ &
\end{tabular}

Hasil analisis ragam yang terlihat dalam Tabel 4 menunjukkan bahwa perlakuan pupuk hayati evagrow berpengaruh sangat nyata terhadap jumlah daun tanaman seledri.
Selanjutnya agar diketahui taraf pemberian pupuk hayati evagrow yang menghasilkan jumlah daun tertinggi dilakukan dengan uji BNJ seperti terlihat dalam Tabel 5. 
Tabel 5. Uji BNJ pemberian pupuk hayati evagrow terhadap jumlah daun (helai)

\begin{tabular}{|c|c|c|c|c|c|c|}
\hline Perlakuan & Rerata & & & Beda & & \\
\hline $\mathrm{E}_{0}$ & $16,20 \mathrm{a}$ & - & & & & \\
\hline $\mathrm{E}_{1}$ & $19,10 \mathrm{a}$ & $2,90^{\mathrm{tn}}$ & - & & & \\
\hline $\mathrm{E}_{3}$ & $28,10 \mathrm{~b}$ & $11,90^{* *}$ & $9,00^{* *}$ & - & & \\
\hline $\mathrm{E}_{4}$ & $29,70 \mathrm{~b}$ & $13,50^{* *}$ & $10,60^{* * *}$ & $1,60^{\text {tn }}$ & - & \\
\hline $\mathrm{E}_{5}$ & $35,60 \mathrm{c}$ & $19,40^{* *}$ & $16,50^{* * *}$ & $7,50^{* *}$ & $5,90^{*}$ & - \\
\hline $\mathrm{E}_{6}$ & $42,80 \mathrm{~d}$ & $26,60^{* *}$ & $23,70^{* * *}$ & $14,70^{* *}$ & $13,10^{* *}$ & $7,20^{* *}$ \\
\hline \multicolumn{3}{|c|}{ BNJ $0,05=5,50$} & \multicolumn{4}{|c|}{ BNJ $0.01=6,88$} \\
\hline Sumber & \multicolumn{6}{|c|}{ : Data pengamatan, 2017} \\
\hline Keterangan & $\begin{array}{ll}: \operatorname{tn} & = \\
* & = \\
* * & =\end{array}$ & \multicolumn{5}{|c|}{$\begin{array}{l}=\text { beda tidak nyata pada taraf } 95 \% \\
=\text { beda nyata pada teraf } 95 \% \\
=\text { beda sangat nvata nada taraf } 99 \%\end{array}$} \\
\hline
\end{tabular}

Angka yang tandai huruf sama menunjukkan tidak beda nyata pada tarf $95 \%$

Hasil uji BNJ yang tertera dalam Tabel 5 diketahui bahwa jumlah daun tertinggi terjadi pada tanaman yang diberi 10 gram evagrow dengan jumlah rata-rata 42,80 helai per tanaman. Pemberian 5 gram evagrow menghasilkan jumlah daun yang tidak lebih banyak dari yang dihasilkan oleh tanaman dengan pemberian 2,5 gram, namun lebih banyak dari daun tanaman dengan pemberian 12,5 gram dan tanpa diberi evagrow.

\section{Berat Segar}

Data rerata hasil pengamatan per tanaman ditampilkan dalam Tabel 6.

Tabel 6. Data rerata pengataman berat segar $(\mathrm{g})$

\begin{tabular}{|c|c|c|c|c|c|c|c|}
\hline \multirow{2}{*}{ Perlakuan } & \multicolumn{5}{|c|}{ Ulangan } & \multirow{2}{*}{ Jumlah } & \multirow{2}{*}{ Rerata } \\
\hline & I & II & III & IV & $\mathrm{V}$ & & \\
\hline $\mathrm{E}_{0}$ & 15,00 & 20,00 & 35,00 & 30,00 & 25,00 & 125,00 & 25,00 \\
\hline $\mathrm{E}_{1}$ & 60,00 & 35,00 & 47,50 & 50,00 & 22,50 & 215,00 & 43,00 \\
\hline $\mathrm{E}_{3}$ & 30,00 & 47,50 & 50,00 & 50,00 & 40,00 & 217,50 & 43,50 \\
\hline $\mathrm{E}_{4}$ & 50,00 & 50,00 & 60,00 & 60,00 & 50,00 & 270,00 & 54,00 \\
\hline $\mathrm{E}_{5}$ & 75,00 & 60,00 & 60,00 & 60,00 & 75,00 & 330,00 & 66,00 \\
\hline $\mathrm{E}_{6}$ & 15,00 & 60,00 & 45,00 & 40,00 & 21,50 & 181,50 & 36,30 \\
\hline Total & 245,00 & 272,50 & 297,50 & 290,00 & 234,00 & 1339,00 & 44,63 \\
\hline
\end{tabular}

Sumber: Data pengamatan, 2017

Data hasil pengamatan berat segar tanaman yang diperlihatkan dalam Tabel 6 dianalisis dengan analisis sidik ragam dan hasilnya seperti pada Tabel 7. 
Tabel 7. Analisis ragam pengaruh pupuk hayati evagrow terhadap berat segar $(\mathrm{g})$

\begin{tabular}{|c|c|c|c|c|c|c|}
\hline \multirow{2}{*}{ SK } & \multirow{2}{*}{ DB } & \multirow{2}{*}{ JK } & \multirow{2}{*}{ KT } & \multirow{2}{*}{ F-hitung } & \multicolumn{2}{|c|}{ F-tabel } \\
\cline { 5 - 7 } & & & & & 0,05 & 0,01 \\
\hline Ulangan & 4 & 509,88 & 127,47 & $0,98^{\text {tn }}$ & 2,87 & 4,43 \\
Perlakuan & 5 & 5015,67 & 1003,13 & $7,74^{* *}$ & 2,71 & 4,10 \\
Galat & 20 & 2591,42 & 129,57 & & & \\
\hline Total & 29 & 8116,97 & & \multicolumn{2}{|c|}{$\mathrm{kk}=25,50 \%$} \\
\hline
\end{tabular}

Sumber : Data pengamatan, 2017

Keterangan : tn = pengaruh tidak nyata pada taraf $95 \%$ ** = pengaruh nyata pada taraf $99 \%$

Hasil analisis ragam pada Tabel 7 menunjukkan bahwa perlakuan pupuk hayati evagrow berpengrauh sangat nyata terhadap berat segar tanaman seledri. Selanjutnya agar diketahui taraf pemberian pupuk hayati evagrow yang menghasilkan berat segar tertinggi dilakukan dengan uji BNJ seperti terlihat dalam Tabel 8.

Tabel 8. Uji BNJ pemberian pupuk hayati evagrow terhadap berat segar (g)

\begin{tabular}{|c|c|c|c|c|c|c|}
\hline Perlakuan & Rerata & & & Beda & & \\
\hline $\mathrm{E}_{0}$ & $25,00 \mathrm{a}$ & - & & & & \\
\hline $\mathrm{E}_{1}$ & $36,30 \mathrm{~b}$ & $11,30^{* *}$ & - & & & \\
\hline $\mathrm{E}_{3}$ & $43,00 \mathrm{~b}$ & $18,00^{* *}$ & $6,70^{\text {tn }}$ & - & & \\
\hline $\mathrm{E}_{4}$ & $43,50 \mathrm{~b}$ & $18,50^{* *}$ & $7,20^{\operatorname{tn}}$ & $0,50^{\mathrm{tn}}$ & - & \\
\hline $\mathrm{E}_{5}$ & $54,00 \mathrm{c}$ & $29,00^{* *}$ & $17,70^{* *}$ & $11,00^{*}$ & $10,50^{*}$ & - \\
\hline $\mathrm{E}_{6}$ & $66,00 \mathrm{~d}$ & $41,00^{* *}$ & $29,70^{* *}$ & $23,00^{* * *}$ & $22,50^{* *}$ & $12,00^{*}$ \\
\hline \multicolumn{3}{|c|}{ BNJ $0,05=9,63$} & \multicolumn{4}{|c|}{ BNJ $0.01=12,04$} \\
\hline
\end{tabular}

Sumber : Data pengamatan, 2017

Keterangan $:$ tn $=$ beda tidak nyata pada taraf $95 \%$

$* \quad=$ beda nyata pada teraf $95 \%$

** = beda sangat nyata pada taraf $99 \%$

Angka yang tandai huruf sama menunjukkan tidak beda nyata pada tarf $95 \%$

Hasil uji BNJ pada Tabel 8 gram, kemudian pada pemberian 7,5 memperlihatkan bahwa berat segar tertinggi dicapai pada pemberian 10 gram pupuk hayati evagrow, berat segar rata-rata per tanaman dihasilkan 66,00 gram juga menghasilkan rata-rata berat segar tertinggi bila dibandingkan dengan pemberian 2,5 gram, 5 gram, dan 12,5 gram. Pada pemberian 2,5 
gram, 5 gram, dan 12,5 gram menghasilkan rata-rata berat segar yang tidak lebih baik per tanaman, tetapi lebih berat dari tanaman tanpa diberi pupuk hayati evagrow.

\section{Pembahasan}

Hasil pengamatan dan analisis data diketahui bahwa pemberian pupuk hayati evagrow memberi pengaruh nyata terhadap pertumbuhan dan hasil tanaman seledri. Pengaruh nyata ini terlihat pada peubah tinggi tanaman, jumlah daun per tanaman, dan berat segar per tanaman. Pengaruh nyata pada pertumbuhan dan hasil tanaman seledri akibat pemberian pupuk hayati evagrow disebabkan oleh mikroba yang ada pada pupuk tersebut dapat mendekomposisi bahan-bahan organik dalam tanah sehingga sifat fisik dan kimia tanah menjadi baik dan unsur hara yang diperlukan tanaman menjadi tersedia. Unsur-unsur hara yang tadinya terikat oleh ion-ion tanah menjadi terbebaskan karena bantuan mikroba dari pupuk evagrow. Unsur-unsur hara yang diperlukan oleh tanaman berupa N, P, $\mathrm{K}, \mathrm{Ca}$, dan $\mathrm{S}$ serta unsur hara mikro. Lakitan (2001:67-69) menjelaskan bahwa unsur $\mathrm{N}$, $\mathrm{P}$, dan $\mathrm{K}$ merupakan unsur hara yang paling banyak diperlukan oleh tanaman.Tersedianya unsur hara bagi tanaman menyebabkan proses metabolisme pada tanaman menjadi baik, dengan demikian maka tanaman dapat tumbuh dan berproduksi lebih maksimal (Hanafiah, dkk., 2008:137).

Unsur Nitrogen membentuk asam amino sebagai kerangka protein sehingga proses pembelahan, pembesaran serta perpanjangan sel dapat berjalan lancar. Lingga (1990:9) menjelaskan bahwa Nitrogen berperan untuk merangsang pertumbuhan secara keseluruhan. Dwidjoseputro (1992:15) menjelaskan bahwa Nitrogen berperan untuk pembentukan butir hijau daun yang merupakan faktor keharusan untuk berlangsungnya fotosintesis. Menurut Harjadi (1991:96), hasil-hasil fotosintesis sebagian digunakan untuk menyusun jaringan tanaman dan sebagian digunakan untuk kegiatan metabolisme tanaman.

Sarief (1986:13) menjelaskan bahwa unsur Fosfor merupakan jaringan meristematik. Dilanjutkan oleh Rinsema (1983:66), bahwa Fosfor sangat berperan aktif dalam mentransfer energi di dalam sel, berfungsi mengubah karbohidrat dan meningkatkan efisiensi kerja kloroplas. Peranan Fosfor adalah 
memacu pertumbuhan dan

pembentukan sistem perakaran yang

baik dari benih dan tanaman muda, mempercepat pembungaan dan pemasakan buah dan biji, memperbesar persentase pembetukan bunga menjadi buah atau biji, penyusun inti sel, lemak dan protein (Setyamidjaya, 1986:16). Dwidjoseputro (1992:127) menjelaskan bahwa secara umum fungsi unsur Kalium adalah sebagai katalisator dalam pengubahan protein dan asam amino,unsur inijuga penting dalam fotosintesa, penyusun karbohidrat dan protein, penyusun nucleus sel dan pengatur keadaan air dalam sel.

Hasil uji BNJ diketahui bahwa pemberian $10 \mathrm{~g}$ pupuk hayati evagrow menghasilkan pertumbuhan dan hasil tertinggi pada tanaman seledri, bahkan lebih baik dari pemberian 12,5 gram yang merupakan dosis pemberian tertinggi pada percobaan ini. Pemberian 10 gram menghasilkan rata-rata tinggi tanaman, jumlah daun, dan berat segar tertinggi hal ini diduga pada pemberian dosis 10 gram jumlah mikroorganisme dalam pupuk hayati evagrow sudah cukup mampu melepaskan dan menyediakan unsur hara yang dibutuhkan oleh tanaman seledri. Masfufah, dkk (2017) menyatakan bahwa bila suatu tanaman berada dalam kondisi yang menguntungkan seperti tersedianya unsur hara yang berkecukupan menyebabkan pertumbuhan dan hasil yang diberikan menjadi lebih baik.

Pemberian 12,5 gram pupuk hayati evagrow tidak menghasilkan pengaruh yang lebih baik terhadap tinggi tanaman, jumlah daun, dan berat segar. Hal ini diduga karena populasi mikroorganisme yang ada di dalam pupuk hayati ini juga bertambah jumlahnya sehingga menyebabkan adanya persaingan antar mikroba dalam mempertahankan diri untuk mendapatkan makanan. Simanungkalit, dkk (2006) menyatakan, jika populasi mikroba tinggi menyebabkan persaingan antar mikoba dalam mendapatkan nutrisi juga tinggi sehingga tidak optimal dalam menyediakan unsur hara bagi tanaman yang pada akhirnya pengaruh terhadap tanaman juga tidak optimal.

\section{KESIMPULAN DAN SARAN}

\section{Kesimpulan}

Hasil pengamatan dan analisis data dalam penelitian ini disimpulkan bahwa: 
1. Pupuk hayati evagrow berpengaruh nyata terhadap pertumbuhan dan hasil tanaman seledri berdasarkan hasil pengamatan terhadap tinggi tanaman, jumlah daun, dan berat segar tanaman

2. Pemberian 10 gram pupuk hayati evagrow menghasilkan pertumbuhan dan hasil tertinggi tanaman seledri dalam penelitian ini. Tinggi tanaman rata-rata $36,00 \mathrm{~cm}$, jumlah daun ratarata 42,80 daun, dan rata-rata berat segar 66,00 gram per tanaman.

\section{Saran}

Melalui hasil penelitian ini disarankan untuk:

1. Memberikan pupuk hayati evagrow dalam meningkatkan pertumbuhan dan hasil tanaman seledri.

2. Pemberian pupuk hayati evagrow 10 gram per liter air cukup optimal meningkatkan pertumbuhan dan hasil seledri.

\section{DAFTAR PUSTAKA}

AAK. 1992. Petunjuk Praktis Bertanam Sayuran. Kanisius. Yogyakarta.

Buckman, H.O., Brady, N.C. 1982. Ilmu Tanah. Terjemahan soegiman. Bhatara Karya Aksara. Jakarta.

Dwidjoseputro, D., 1984. Pengantar Fisiologi Tumbuhan. PT.
Gramedia Pustaka Utama. Jakarta.

Gaspersz, V., 1994. Metode Perancangan Percobaan. Armico. Bandung.

Hakim, N.,Nyakpa, M.Y., Lubis, A.M., Nugroho, S.G., Saul, M.R., Diha, M.A., Hong, G.B., balley, H.H. 1986. Dasar-Dasar Ilmu Tanah. Universitas Lampung. Bandar Lampung.

Hanafiah, K.A., I. Anas., A. Napoleon., N. Gofar. 2005. Biologi Tanah, Ekologi dan Makrobiologi Tanah. Raja Grafindo Persada. Jakarta.

Hardjadi, M.S.S. 1991. Pengantar Agronomi. Gramedia Pustaka Utama. Jakarta.

Hardjowigeno, S. 1992. Klasifikasi Tanah Dan Pedogenesis. Akademika Pressindo. Jakarta.

Hardjowigeno, S. 2003. Ilmu Tanah. Akademika Pressindo. Jakarta.

Lakitan, B. 1996. Fisiologi Pertumbuhan dan Perkembangan Tanaman. Raja Grafindo Perkasa. Jakarta.

Lingga,P. 1990.Petunjuk Penggunaan Pupuk. Penebar Swadaya. Jakarta.

Masfufah, A., A.Supriyanto., T. Surtiningsih. 2017. Pengaruh Pemberian Pupuk Hayati (Biofertilizer) Pada Berbagai Dosis Pupuk Dan Media Tanam Yang Berbeda Terhadap Pertumbuhan Dan Produktivitas Tanaman Tomat (Lycopersicum 
esculantum) Pada Polybag. Artikel Ilmiah Fakultas Sains dan Teknologi Universitas Airlangga Surabaya.

Nyakpa, M.Y., Lubis, A.M., Pulung, M.A., Amrah, G., Munawar, A., Hong, G.B., dan Hakim, N., 1988.Kesuburan Tanah.: Universitas Lampung. Bandar Lampung

PT. Prosper Biotech Indonesia, 2008. Pupuk Hayati Evagrow. PT. Prosper Biotech Indonesia. Bandung.

Rinsema, W.T., 1983.Pupuk dan Pemupukan. PT. Gramedia. Jakarta.

Rukmana, R. 2003. Bertanam Seledri. Kanisius. Yogyakarta.
Sarief, E.S. 1986. Pemupukan Tanah Pertanian. Pustaka Buana. Bandung.

Setyamidjaya, D.J. 1986. Pupuk dan Pemupukan. Siplex. Jakarta.

Simanungkalit, $\quad$ RDM., $\quad$ D.A. Suriadikarta., R. Saraswati., D. Setyorini., dan W. Hartatik. 2006. Pupuk Organik Dan Pupuk Hayati (Organic Fertilizer and Biofertilizer). Balai Besar Litbang Sumberdaya Lahan Pertanian. Badan Penelitian dan Pengembangan Pertanian.

Soewito, M.D.S. 1991. Bercocok Tanam Seledri.Jakarta: Titik Terang.

Tora, N. 2013. Klasifikasi dan Morfologi Tanaman Seledri (Apium graveolens L.). www.google.com/seledri. 